\title{
Advances in the diagnosis and treatment of sickle cell disease
}

\author{
A. M. Brandow ${ }^{1}$ and R. I. Liem² ${ }^{2^{*}}$
}

\begin{abstract}
Sickle cell disease (SCD), which affects approximately 100,000 individuals in the USA and more than 3 million worldwide, is caused by mutations in the $\beta b$ globin gene that result in sickle hemoglobin production. Sickle hemoglobin polymerization leads to red blood cell sickling, chronic hemolysis and vaso-occlusion. Acute and chronic pain as well as end-organ damage occur throughout the lifespan of individuals living with SCD resulting in significant disease morbidity and a median life expectancy of 43 years in the USA. In this review, we discuss advances in the diagnosis and management of four major complications: acute and chronic pain, cardiopulmonary disease, central nervous system disease and kidney disease. We also discuss advances in disease-modifying and curative therapeutic options for SCD. The recent availability of L-glutamine, crizanlizumab and voxelotor provides an alternative or supplement to hydroxyurea, which remains the mainstay for disease-modifying therapy. Five-year event-free and overall survival rates remain high for individuals with SCD undergoing allogeneic hematopoietic stem cell transplant using matched sibling donors. However, newer approaches to graft-versus-host (GVHD) prophylaxis and the incorporation of posttransplant cyclophosphamide have improved engraftment rates, reduced GVHD and have allowed for alternative donors for individuals without an HLA-matched sibling. Despite progress in the field, additional longitudinal studies, clinical trials as well as dissemination and implementation studies are needed to optimize outcomes in SCD.
\end{abstract}

Keywords Sickle cell disease, Sickle cell anemia, Hemoglobin

\section{Introduction}

Sickle cell disease (SCD), a group of inherited hemoglobinopathies characterized by mutations that affect the $\beta$-globin chain of hemoglobin, affects approximately 100,000 people in the USA and more than 3 million people worldwide $[1,2]$. SCD is characterized by chronic hemolytic anemia, severe acute and chronic pain as well as end-organ damage that occurs across the lifespan. SCD is associated with premature mortality with a

\section{${ }^{*}$ Correspondence:}

R. I. Liem

rliem@luriechildrens.org

1 Department of Pediatrics, Section of Pediatric Hematology/Oncology/ Bone Marrow Transplantation, Medical College of Wisconsin, Milwaukee, WI, USA

${ }^{2}$ Division of Hematology, Oncology and Stem Cell Transplantation, Ann and Robert H. Lurie Children's Hospital of Chicago, Chicago, IL, USA median age of death of 43 years (IQR 31.5-55 years) [3]. Treatment requires early diagnosis, prevention of complications and management of end-organ damage. In this review, we discuss recent advances in the diagnosis and management of four major complications in SCD: acute and chronic pain, cardiopulmonary disease, central nervous system disease and kidney disease. Updates in disease-modifying and curative therapies for SCD are also discussed.

\section{Molecular basis and pathophysiology}

Hemoglobin $\mathrm{S}(\mathrm{HbS})$ results from the replacement of glutamic acid by valine in the sixth position of the $\beta$-globin chain of hemoglobin (Fig. 1). Severe forms of SCD include hemoglobin SS due to homozygous inheritance of $\mathrm{HbS}$ and $\mathrm{S} / \beta^{0}$ thalassemia due to co-inheritance of $\mathrm{HbS}$ with the $\beta^{0}$ thalassemia mutation. Other forms include original author(s) and the source, provide a link to the Creative Commons licence, and indicate if changes were made. The images or other third party material in this article are included in the article's Creative Commons licence, unless indicated otherwise in a credit line to the material. If material is not included in the article's Creative Commons licence and your intended use is not permitted by statutory regulation or exceeds the permitted use, you will need to obtain permission directly from the copyright holder. To view a copy of this licence, visit http://creativecommons.org/licenses/by/4.0/. The Creative Commons Public Domain Dedication waiver (http://creativeco mmons.org/publicdomain/zero/1.0/) applies to the data made available in this article, unless otherwise stated in a credit line to the data. 


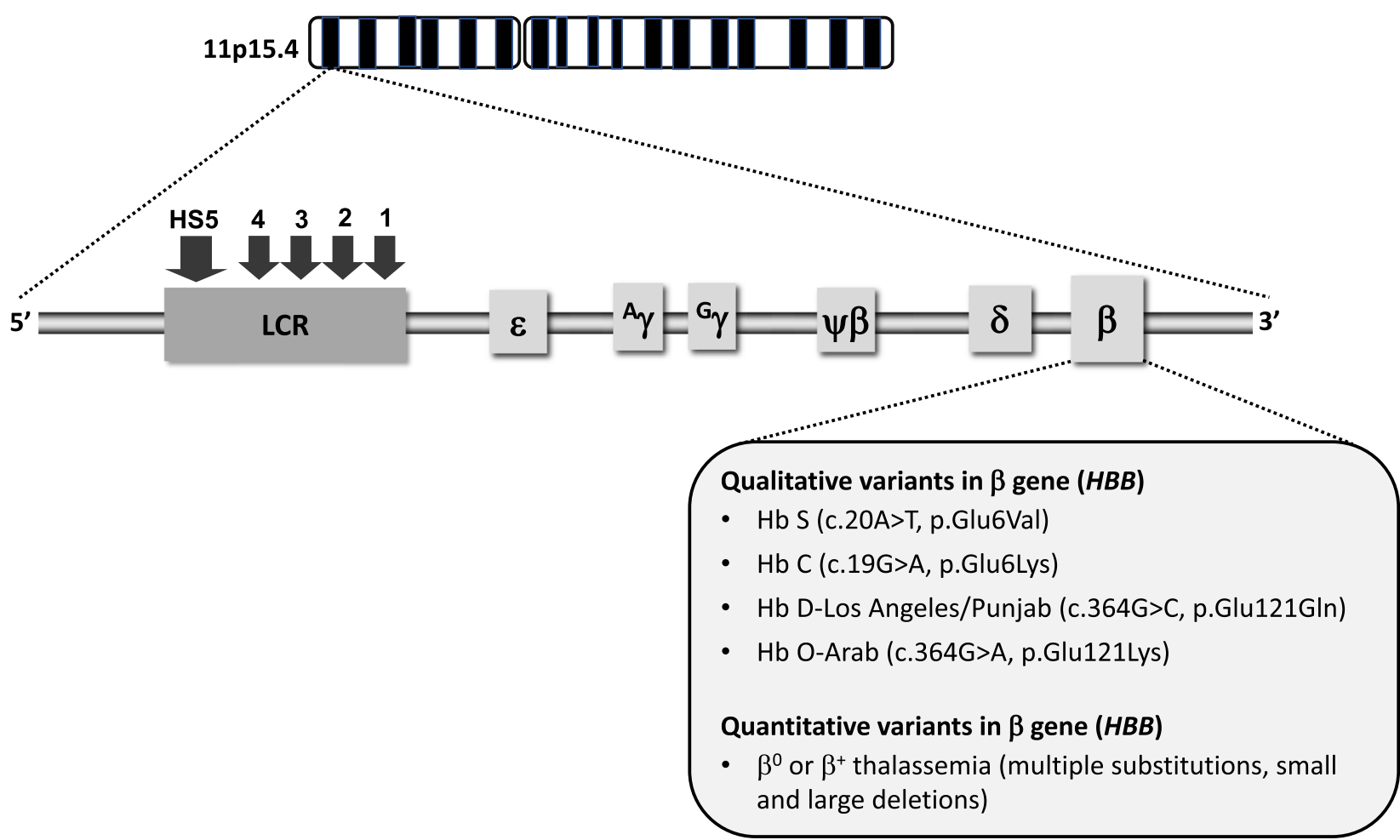

Fig. 1 Genetic and molecular basis of sickle cell disease. SCD is caused by mutations in the $\beta$ globin gene, located on the $\beta$ globin locus found on the short arm of chromosome 11. The homozygous inheritance of $\mathrm{Hb}$ S or co-inheritance of $\mathrm{Hb} S$ with the $\beta^{0}$ thalassemia mutation results in the most common forms of severe SCD. Co-inheritance of $\mathrm{Hb}$ S with other variants such as Hb C, Hb D-Los Angeles/Punjab, Hb O-Arab or $\beta^{+}$ thalassemia also leads to clinically significant sickling syndromes (LCR, locus control region; HS, hypersensitivity site)

co-inheritance of $\mathrm{HbS}$ with other $\beta$-globin gene mutations such as hemoglobin $C$, hemoglobin D-Los Angeles/ Punjab or $\beta^{+}$thalassemia. $\mathrm{Hb} S$ has reduced solubility and increased polymerization, which cause red blood cell sickling, hemolysis and vaso-occlusion (Table 1) that subsequently lead to pain episodes and end-organ damage such as cardiopulmonary, cerebrovascular and kidney disease (Table 2).

\section{Acute and chronic pain}

Severe intermittent acute pain is the most common SCD complication and accounts for over $70 \%$ of acute care visits for individuals with SCD [4]. Chronic daily pain increases with older age, occurring in $30-40 \%$ of adolescents and adults with SCD $[5,6]$. Acute pain is largely related to vaso-occlusion of sickled red blood cells with ischemia-reperfusion injury and tissue infarction and presents in one isolated anatomic location (e.g., arm, leg, back) or multiple locations. Chronic pain can be caused by sensitization of the central and/or peripheral nervous system and is often diffuse with neuropathic pain features $[7,8]$. A consensus definition for chronic pain includes "Reports of ongoing pain on most days over the past 6 months either in a single location or multiple locations" [9]. Disease complications such as avascular necrosis (hip, shoulder) and leg ulcers also cause chronic pain [9].

\section{Diagnosis of acute and chronic pain}

The gold standard for pain assessment and diagnosis is patient self-report. There are no reliable diagnostic tests to confirm the presence of acute or chronic pain in individuals with SCD except when there are identifiable causes like avascular necrosis on imaging or leg ulcers on exam. The effects of pain on individuals' function are assessed using patient-reported outcome measures (PROs) that determine to what extent pain interferes with individuals' daily function. Tools shown to be valid, reliable and responsive can be used in clinical practice to track patients' pain-related function over time to determine additional treatment needs and to compare to population norms [10]. There are currently no plasma pain biomarkers that improve assessment and management of SCD acute or chronic pain. 
Table 1 Sickle cell disease

Epidemiology

Molecular basis and pathophysiology

Major complications and disease burden
SCD affects primarily individuals of African or Afro-Caribbean descent

1 in 12 individuals are carriers for sickle cell trait

1 in 365 Black infants in the US are affected by SCD

Approximately 100,000 individuals in the US and millions more worldwide have SCD

Mutation is caused by single nucleotide substitution in the 6 th codon of $\beta$-globin gene $(H B B)$

Mutation results in production of sickle hemoglobin

Common genotypes are homozygous SS disease (HbSS) and the compound heterozygous states $\mathrm{HbSC}, \mathrm{HbS} / \mathrm{\beta}^{0}$ and $\mathrm{HbS} / \beta^{+}$thalassemia

Mutation leads to reduced solubility of sickle hemoglobin and increased polymerization

Pathophysiological contributors include red blood cell sickling, hemolysis, vasoocclusion, cell adhesion, pro-inflammatory state, oxidative injury, endothelial dysfunction and hypercoagulability

Acute pain and chronic pain syndrome
Functional asplenia and infection
Splenic sequestration
Acute chest syndrome
Cerebrovascular disease and stroke
Neurocognitive deficits
Retinopathy
Priapism
Chronic lung disease
Pulmonary hypertension
Skin ulcers
Osteonecrosis
Chronic kidney disease

Table 2 Prevalence and pathophysiologic basis of major complications in SCD

\begin{tabular}{|c|c|c|}
\hline & Prevalence & Pathophysiology and/or risk factors \\
\hline Acute and chronic pain & $\begin{array}{l}\text { Acute pain-represents } 70 \% \text { of acute care visits } \\
\text { Chronic pain-30\% in adults, } 40 \% \text { in children }\end{array}$ & $\begin{array}{l}\text { Tissue ischemia and infarction } \\
\text { Ischemia-reperfusion injury } \\
\text { Hemolysis-induced endothelial dysfunction } \\
\text { Inflammation and oxidative stress } \\
\text { Peripheral and central nervous system sensitization } \\
\text { Identifiable causes such as avascular necrosis and leg ulcers }\end{array}$ \\
\hline Pulmonary hypertension & $10 \%$ in adults by right-heart catheterization & $\begin{array}{l}\text { Intravascular hemolysis } \\
\text { Nitric oxide depletion } \\
\text { Chronic hypoxia } \\
\text { Diastolic dysfunction } \\
\text { Diffuse myocardial fibrosis }\end{array}$ \\
\hline Chronic lung disease & $\begin{array}{l}\text { Obstructive lung disease-16\% children, } 8 \% \text { adults } \\
\text { Restrictive lung disease }-7 \% \text { children, } 28 \% \text { adults }\end{array}$ & $\begin{array}{l}\text { Obstructive lung disease_-atopy, airway inflammation ( } \uparrow \text { leukotrienes) } \\
\text { Restrictive lung disease_-recurrent acute chest syndrome }\end{array}$ \\
\hline Stroke & $\begin{array}{l}\text { Overt stroke-11\% by } 20 \text { years old } \\
\text { Silent cerebral infarct-39\% by } 18 \text { years old }\end{array}$ & $\begin{array}{l}\text { Cerebral vasculopathy } \\
\downarrow \text { Blood oxygen content, } \uparrow \text { cerebral blood flow and } \uparrow \text { oxygen extrac- } \\
\text { tion } \\
\text { Nocturnal hypoxemia } \\
\text { Moyamoya }\end{array}$ \\
\hline Sickle nephropathy & Chronic kidney disease -20 to $40 \%$ of adults & $\begin{array}{l}\text { Medullary hypoperfusion and ischemia } \\
\text { Glomerular hemodynamic alterations } \\
\text { Hemolysis-induced oxidative injury } \\
\text { Endothelial damage } \\
\text { Vascular congestion } \\
\text { Hypoxia-inducible factor-1a dependent injury }\end{array}$ \\
\hline
\end{tabular}

Depression and anxiety as co-morbid conditions in SCD can contribute to increased pain, more pain-related distress/interference and poor coping [11]. The prevalence of depression and anxiety range from $26-33 \%$ and 6.5-36\%, respectively, in adults with SCD [11-13]. Adults with SCD have an $11 \%$ higher prevalence of depression compared to Black American adults without SCD [14]. Depression and anxiety can be assessed using 
self-reported validated screening tools (e.g., Depression: Patient Health Questionnaire (PHQ-9) [15] for adults, Center for Epidemiologic Studies Depression Scale for Children (CES-DC) [16], PROMIS assessments for adults and children; Anxiety: Generalized Anxiety Disorder 7-item (GAD-7) scale for adults, State-Trait Anxiety Inventory for Children (STAIC) [17], PROMIS assessments for adults and children). Individuals who screen positive using these tools should be referred for evaluation by a psychologist/psychiatrist.

\section{Management of acute and chronic pain}

The goal of acute pain management is to provide sufficient analgesia to return patients to their usual function, which may mean complete resolution of pain for some or return to baseline chronic pain for others. The goal of chronic pain management is to optimize individuals' function, which may not mean being pain free. When there is an identifiable cause of chronic pain, treatment of the underlying issue (e.g., joint replacement for avascular necrosis, leg ulcer treatment) is important. Opioids, oral for outpatient management and intravenous for inpatient management, are first line therapy for acute SCD pain. In the acute care setting, analgesics should be initiated within 30-60 min of triage [18]. Ketamine, a non-opioid analgesic, can be prescribed at sub-anesthetic (analgesic) intravenous doses $(0.1-0.3 \mathrm{mg} / \mathrm{kg}$ per $\mathrm{h}$, maximum $1 \mathrm{mg} / \mathrm{kg}$ per h) as adjuvant treatment for acute SCD pain refractory to opioids $[18,19]$. In an uncontrolled observational study of 85 patients with SCD receiving ketamine infusions for acute pain, ketamine was associated with a decrease in mean opioid consumption by oral morphine equivalents ( 3.1 vs. $2.2 \mathrm{mg} / \mathrm{kg} / \mathrm{day}, p<0.001$ ) and reductions in mean pain scores $(0-10$ scale) from baseline until discontinuation of the infusion (7.81 vs. $5.44, p<0.001$ ) [20]. Nonsteroidal anti-inflammatory drugs (NSAIDs) are routinely used as adjuvant therapy for acute pain treatment [18]. In a RCT $(n=20)$ of hospitalized patients with acute pain, ketorolac was associated with lower total dose of meperidine required $(1866.7 \pm 12.4$ vs. $2804.5 \pm 795.1 \mathrm{mg}, p<0.05)$ and shorter hospitalization (median 3.3 vs. 7.2 days, $p=0.027$ ) [21]. In a case series of children treated for 70 acute pain events in the ED, 53\% of events resolved with ketorolac and hydration alone with reduction in $100 \mathrm{~mm}$ visual analog scale (VAS) pain score from 60 to $13(p<0.001)$ [22]. Patients at risk for NSAID toxicity (e.g., renal impairment, on anticoagulation) should be identified.

Despite paucity of data, chronic opioid therapy (COT) can be considered after assessing benefits versus harms [23] and the functional status of patients with SCD who have chronic pain. Harms of COT seen in patient populations other than SCD are dose dependent and include myocardial infarction, bone fracture, increased risk of motor vehicle collisions, sexual dysfunction and mortality [23]. There are few published studies investigating non-opioid analgesics for chronic SCD pain [24-26]. In a randomized trial of 39 participants, those who received Vitamin D experienced a range of 6-10 pain days over 24 weeks while those who received placebo experienced 10-16 pain days, which was not significantly different [26]. In a phase 1 , uncontrolled trial of 18 participants taking trifluoperazine, an antipsychotic drug, 8 participants showed a $50 \%$ reduction in the VAS (10 $\mathrm{cm}$ horizontal line) pain score from baseline on at least 3 assessments over $24 \mathrm{~h}$ without severe sedation or supplemental opioid analgesics, 7 participants showed pain reduction on 1 assessment, and the remaining 3 participants showed no reduction [24]. Although published data are not available for serotonin and norepinephrine reuptake inhibitors (SNRIs), gabapentinoids and tricyclic antidepressants (TCAs) in individuals with SCD, evidence supports their use in fibromyalgia, a chronic pain condition similar to SCD chronic pain in mechanism. A Cochrane Review that included 10 RCTs $(n=6038)$ showed that the SNRIs milnacipran and duloxetine, compared to placebo, were associated with a reduction in pain [27]. A systematic review and meta-analysis of 9 studies $(n=520)$ showed the TCA amitriptyline improved pain intensity and function [28]. Finally, a meta-analysis of 5 RCTs $(n=1874)$ of the gabapentinoid pregabalin showed a reduction in pain intensity [29]. Collectively, the indirect evidence from fibromyalgia supports the conditional recommendation in current SCD practice guidelines to consider these 3 drug classes for chronic SCD pain treatment [18]. Standard formulary dosing recommendations should be followed and reported adverse effects considered.

Non-pharmacologic therapies (e.g., integrative, psychological-based therapies) are important components of SCD pain treatment. In a case-control study of 101 children with SCD and chronic pain referred for cognitive behavioral therapy (CBT) (57 CBT, 44 no CBT) [30], CBT was associated with more rapid decrease in pain hospitalizations (estimate $-0.63, p<0.05)$ and faster reduction in hospital days over time (estimate $-5.50, p<0.05$ ). Among 18 children who received CBT and completed PROs pre- and 12 months posttreatment, improvements were seen in mean pain intensity (5.47 vs. 3.76, $p=0.009$; $0-10$ numeric rating pain scale), functional disability (26.24 vs. $15.18, p<0.001 ; 0-60$ score range) and pain coping ( 8.00 vs. $9.65, p=0.03 ; 3-15$ score range) post treatment [30]. In 2 uncontrolled clinical trials, acupuncture was associated with a significant reduction in pain scores by 2.1 points $(0-10$ numeric pain scale) in 24 participants immediately after treatment [31] or a significant 
mean difference in pre-post pain scores of $0.9333(0-10$ numeric pain scale) $(p<0.000)$ after 33 acupuncture sessions [32].

\section{Cardiopulmonary disease}

Cardiopulmonary disease is associated with increased morbidity and mortality in individuals with SCD. Pulmonary hypertension $(\mathrm{PH})$, most commonly pulmonary arterial hypertension (PAH), is present based on rightheart catheterization in up to $10 \%$ of adults with SCD [33]. Chronic intravascular hemolysis represents the biggest risk factor for development of PAH in SCD and leads to pulmonary arteriole vasoconstriction and smooth muscle proliferation. Based on pulmonary function testing (PFT), obstructive lung disease may be observed in $16 \%$ of children and $8 \%$ of adults with SCD, while restrictive lung disease may be seen in up to $28 \%$ of adults and only $7 \%$ of children with SCD [34,35]. Sleep-disordered breathing, which can manifest as obstructive sleep apnea or nocturnal hypoxemia, occurs in up to $42 \%$ of children and $46 \%$ of adults with SCD [36, 37]. Cardiopulmonary disease, including $\mathrm{PH}$ or restrictive lung disease, presents with dyspnea with or without exertion, chest pain, hypoxemia or exercise intolerance that is unexplained or increased from baseline. Obstructive lung disease can also present with wheezing.

\section{Diagnosis of cardiopulmonary disease}

The confirmation of $\mathrm{PH}$ in patients with $\mathrm{SCD}$ requires right-heart catheterization. Recently, the mean pulmonary artery pressure threshold used to define $\mathrm{PH}$ in the general population was lowered from $\geq 25$ to $\geq 20 \mathrm{~mm}$ $\mathrm{Hg}$ [38]. Elevated peak tricuspid regurgitant jet velocity $(\mathrm{TRJV}) \geq 2.5 \mathrm{~m} / \mathrm{s}$ on Doppler echocardiogram (ECHO) is associated with early mortality in adults with SCD and may suggest elevated pulmonary artery pressures, especially when other signs of PH (e.g., right-heart strain, septal flattening) or left ventricular diastolic dysfunction, which may contribute to $\mathrm{PH}$, are present [39]. However, the positive predictive value (PPV) of peak TRJV alone for identifying $\mathrm{PH}$ in adults with SCD is only $25 \%$ [40]. Increasing the peak TRJV threshold to at least $2.9 \mathrm{~m} / \mathrm{s}$ has been shown to increase the PPV to $64 \%$. For a peak TRJV of $2.5-2.8 \mathrm{~m} / \mathrm{s}$, an increased N-terminal pro-brain natriuretic peptide (NT-proBNP) $\geq 164.5 \mathrm{pg} / \mathrm{mL}$ or a reduced 6-min walk distance $(6 \mathrm{MWD})<333 \mathrm{~m}$ can also improve the PPV to $62 \%$ with a false negative rate of $7 \%$ $[33,40,41]$.

PFT, which includes spirometry and measurement of lung volumes and diffusion capacity, is standard for diagnosing obstructive and restrictive lung disease in patients with SCD. Emerging modalities include impulse oscillometry, a non-invasive method using forced sound waves to detect changes in lower airway mechanics in individuals unable to perform spirometry [42], and airway provocation studies using cold air or methacholine to reveal latent airway hyperreactivity [43]. Formal in-lab, sleep study/polysomnography remains the gold standard to evaluate for sleep-disordered breathing, which may include nocturnal hypoxemia, apnea/hypopnea events and other causes of sleep disruption. Nocturnal hypoxemia may increase red blood cell sickling, cellular adhesion and endothelial dysfunction. In 47 children with SCD, mean overnight oxygen saturation was higher in those with grade 0 compared to grade 2 or 3 cerebral arteriopathy $(97 \pm 1.6$ vs. $93.9 \pm 3.7$ vs. $93.5 \pm 3.0 \%$, $p<0.01)$ on magnetic resonance angiography and lower overnight oxygen saturation was independently associated with mild, moderate or severe cerebral arteriopathy after adjusting for reticulocytosis (OR 0.50, 95\% CI 0.26$0.96, p<0.05)[44]$.

\section{Management of cardiopulmonary disease}

Patients with SCD who have symptoms suggestive of cardiopulmonary disease, such as worsening dyspnea, hypoxemia or reduced exercise tolerance, should be evaluated with a diagnostic ECHO and PFT. The presence of snoring, witnessed apnea, respiratory pauses or hypoxemia during sleep, daytime somnolence or nocturnal enuresis in older children and adults is sufficient for a diagnostic sleep study.

Without treatment, the mortality rate in SCD patients with $\mathrm{PH}$ is high compared to those without (5-year, allcause mortality rate of 32 vs. $16 \%, p<0.001$ ) [33]. PAHtargeted therapies should be considered for SCD patients with PAH confirmed by right-heart catheterization. However, the only RCT $(n=6)$ in individuals with SCD and PAH confirmed by right-heart catheterization (bosentan versus placebo) was stopped early for poor accrual with no efficacy endpoints analyzed [45]. In SCD patients with elevated peak TRJV, a randomized controlled trial $(n=74)$ of sildenafil, a phosphodiesterase- 5 inhibitor, was discontinued early due to increased pain events in the sildenafil versus placebo arm ( 35 vs. $14 \%, p=0.029$ ) with no treatment benefit [46]. Despite absence of clinical trial data, patients with SCD and confirmed PH should be considered for hydroxyurea or monthly red blood cell transfusions given their disease-modifying benefits. In a retrospective analysis of 13 adults with SCD and PAH, $77 \%$ of patients starting at a New York Heart Association (NYHA) functional capacity class III or IV achieved class I/II after a median of 4 exchange transfusions with improvement in median pulmonary vascular resistance (3.7 vs. 2.8 Wood units, $p=0.01$ ) [47].

Approximately $28 \%$ of children with SCD have asthma, which is associated with increased pain episodes that 
may result from impaired oxygenation leading to sickling and vaso-occlusion as well as with acute chest syndrome and higher mortality [48-50]. First line therapies include standard beta-adrenergic bronchodilators and supplemental oxygen as needed. When corticosteroids are indicated, courses should be tapered over several days given the risk of rebound SCD pain from abrupt discontinuation. Inhaled corticosteroids such as fluticasone proprionate or beclomethasone diproprionate are reserved for patients with recurrent asthma exacerbations, but their anti-inflammatory effects and impact on preventing pain episodes in patients with SCD who do not have asthma is under investigation [51]. Finally, management of sleep-disordered breathing is tailored to findings on formal sleep study in consultation with a sleep/pulmonary specialist.

\section{Central nervous system (CNS) complications}

CNS complications, such as overt and silent cerebral infarcts, cause significant morbidity in individuals with SCD. Eleven percent of patients with HbSS disease by age 20 years and $24 \%$ by age 45 years will have had an overt stroke [52]. Silent cerebral infarcts occur in 39\% by 18 years and in $>50 \%$ by 30 years [53, 54]. Patients with either type of stroke are at increased risk of recurrent stroke [55]. Overt stroke involves large-arteries, including middle cerebral arteries and intracranial internal carotid arteries, while silent cerebral infarcts involve penetrating arteries. The pathophysiology of overt stroke includes vasculopathy, increased sickled red blood cell adherence, and hemolysis-induced endothelial activation and altered vasomotor tone [56]. Overt strokes present as weakness or paresis, dysarthria or aphasia, seizures, sensory deficits, headache or altered level of consciousness, while silent cerebral infarcts are associated with cognitive deficits, including lower IQ and impaired academic performance.

\section{Diagnosis of CNS complications in SCD}

Overt stroke is diagnosed by evidence of acute infarct on brain MRI diffusion-weighted imaging and focal deficit on neurologic exam. A silent cerebral infarct is defined by a brain "MRI signal abnormality at least $3 \mathrm{~mm}$ in one dimension and visible in 2 planes on fluid-attenuated inversion recovery (FLAIR) T2-weighted images" and no deficit on neurologic exam [57]. Since silent cerebral infarcts cannot be detected clinically, a screening baseline brain MRI is recommended in school-aged children with SCD [58]. Recent SCD clinical practice guidelines also suggest a screening brain MRI in adults with SCD to facilitate rehabilitation services, patient and family understanding of cognitive deficits and further needs assessment [58]. An MRA should be added to screening/ diagnostic MRIs to evaluate for cerebral vasculopathy (e.g., moyamoya), which may increase risk for recurrent stroke or hemorrhage [59].

Annual screening for increased stroke risk by transcranial doppler (TCD) ultrasound is recommended by the American Society of Hematology for children 2-16 years old with $\mathrm{HbSS}$ or $\mathrm{HbS} / \beta^{\circ}$ thalassemia [58]. Increased stroke risk on non-imaging TCD is indicated by abnormally elevated cerebral blood flow velocity, defined as $\geq 200 \mathrm{~cm} / \mathrm{s}$ (time-averaged mean of the maximum velocity) on 2 occasions or a single velocity of $>220 \mathrm{~cm} / \mathrm{s}$ in the distal internal carotid or proximal middle cerebral artery [60]. Many centers rely on imaging TCD, which results in velocities $10-15 \%$ lower than values obtained by non-imaging protocols and therefore, require adjustments to cut-offs for abnormal velocities. Data supporting stroke risk assessment using TCD are lacking for adults with SCD and standard recommendations do not exist.

Neurocognitive deficits occur in over $30 \%$ of children and adults with severe SCD [61,62]. These occur as a result of overt and/or silent cerebral infarcts but in some patients, the etiology is unknown. The Bright Futures Guidelines for Health Supervision of Infants, Children and Adolescents or the Cognitive Assessment Toolkit for adults are commonly used tools to screen for developmental delays or neurocognitive impairment [58]. Abnormal results should prompt referral for formal neuropsychological evaluation, which directs the need for brain imaging to evaluate for silent cerebral infarcts and facilitate educational/vocational accommodations.

\section{Management of CNS complications}

Monthly chronic red blood cell transfusions to suppress $\mathrm{HbS}<30 \%$ are standard of care for primary stroke prevention in children with an abnormal TCD. In an RCT of 130 children, chronic transfusions, compared to no transfusions, were associated with a difference in stroke risk of 92\% ( 1 vs. 10 strokes, $p<0.001$ ) [60]. However, children with abnormal TCD and no MRI/MRA evidence of cerebral vasculopathy can safely transition to hydroxyurea after 1 year of transfusions [63]. Lifelong transfusions to maintain $\mathrm{HbS}<30 \%$ remain standard of care for secondary stroke prevention in individuals with overt stroke [64]. Chronic monthly red blood cell transfusions should also be considered for children with silent cerebral infarct [58]. In a randomized controlled trial $(n=196)$, monthly transfusions, compared to observation without hydroxyurea, reduced risk of overt stroke, new silent cerebral infarct or enlarging silent cerebral infarct in children with $\mathrm{HbSS}$ or $\mathrm{HbS} / \beta^{0}$ thalassemia and an existing silent 
cerebral infarct ( 2 vs. 4.8 events, incidence rate ratio of $0.41,95 \%$ CI $0.12-0.99, p=0.04$ ) [57].

Acute stroke treatment requires transfusion therapy to increase cerebral oxygen delivery. Red blood cell exchange transfusion, defined as replacement of patients' red blood cells with donor red blood cells, to rapidly reduce $\mathrm{HbS}$ to $<30 \%$ is the recommended treatment as simple transfusion alone is shown to have a fivefold greater relative risk (57 vs. $21 \%$ with recurrent stroke, $\mathrm{RR}=5.0$; 95\% CI 1.3-18.6) of subsequent stroke compared to exchange transfusion [65]. However, a simple transfusion is often given urgently while preparing for exchange transfusion [58]. Tissue plasminogen activator (tPA) is not recommended for children with SCD who have an acute stroke since the pathophysiology of SCD stroke is less likely to be thromboembolic in origin and there is risk for harm. Since the benefits and risks of tPA in adults with SCD and overt stroke are not clear, its use depends on co-morbidities, risk factors and stroke protocols but should not delay or replace prompt transfusion therapy.

Data guiding treatment of SCD cerebral vasculopathy (e.g., moyamoya) are limited, and only nonrandomized, low-quality evidence exists for neurosurgical interventions (e.g., encephaloduroarteriosynangiosis) [66]. Consultation with a neurosurgeon to discuss surgical options in patients with moyamoya and history of stroke or transient ischemic attack should be considered [58].

\section{Kidney disease}

Glomerulopathy, characterized by hyperfiltration leading to albuminuria, is an early asymptomatic manifestation of SCD nephropathy and worsens with age. Hyperfiltration, defined by an absolute increase in glomerular filtration rate, may be seen in $43 \%$ of children with SCD [67]. Albuminuria, defined by the presence of urine albu$\min \geq 30 \mathrm{mg} / \mathrm{g}$ over $24 \mathrm{~h}$, has been observed in $32 \%$ of adults with SCD [68]. Glomerulopathy results from intravascular hemolysis and endothelial dysfunction in the renal cortex. Medullary hypoperfusion and ischemia also contribute to kidney disease in SCD, causing hematuria, urine concentrating defects and distal tubular dysfunction [69]. Approximately $20-40 \%$ of adults with SCD develop chronic kidney disease (CKD) and are at risk of developing end-stage renal disease (ESRD), with rapid declines in estimated glomerular filtration rate (eGFR) $>3 \mathrm{~mL} / \mathrm{min} / 1.73 \mathrm{~m}^{2}$ associated with increased mortality (HR 2.4, 95\% CI 1.31-4.42, $p=0.005$ ) [68].

\section{Diagnosis of kidney disease in SCD}

The diagnosis of sickle cell nephropathy is made by detecting abnormalities such as albuminuria, hematuria or CKD rather than by distinct diagnostic criteria in
SCD, which have not been developed. Traditional markers of kidney function such as serum creatinine and eGFR should be interpreted with caution in individuals with SCD because renal hyperfiltration affects their accuracy by increasing both. Practical considerations preclude directly measuring GFR by urine or plasma clearance techniques, which achieves the most accurate results. The accuracy of eGFR, however, may be improved by equations that incorporate serum cystatin $C$ [70].

Since microalbuminuria/proteinuria precedes CKD in SCD, annual screening for urine microalbumin/protein is recommended beginning at age 10 years [71]. When evaluating urine for microalbumin concentration, samples from first morning rather than random voids are preferable to exclude orthostatic proteinuria. Recent studies suggest $H M O X 1$ and $A P O L 1$ gene variants may be associated with CKD in individuals with SCD [72]. Potential novel predictors of acute kidney injury in individuals with SCD include urine biomarkers kidney injury molecule 1 (KIM-1) [73], monocyte chemotactic protein 1 (MCP-1) [74] and neutrophil gelatinase-associated lipocalin (NGAL) [75]. Their contribution to chronic kidney disease and interaction with other causes of kidney injury in SCD (e.g., inflammation, hemolysis) are not clear.

\section{Management of kidney disease}

Managing kidney complications in SCD should focus on mitigating risk factors for acute and chronic kidney injury such as medication toxicity, reduced kidney perfusion from hypotension and dehydration, and general disease progression, as well as early screening and treatment of microalbuminuria/proteinuria. Acute kidney injury, either an increase in serum creatinine $\geq 0.3 \mathrm{mg} / \mathrm{dL}$ or a $50 \%$ increase in serum creatinine from baseline, is associated with ketorolac use in children with SCD hospitalized for pain [76]. Increasing intravenous fluids to maintain urine output $>0.5$ to $1 \mathrm{~mL} / \mathrm{kg} / \mathrm{h}$ and limiting NSAIDs and antibiotics associated with nephrotoxicity in this setting are important. Despite absence of controlled clinical trials, hydroxyurea may be associated with improvements in glomerular hyperfiltration and urine concentrating ability in children with SCD [77, 78]. Hydroxyurea is also associated with a lower prevalence (34.7 vs. $55.4 \%$, $p=0.01$ ) and likelihood of albuminuria (OR $0.28,95 \% \mathrm{CI}$ $0.11-0.75, p=0.01$ ) in adults with SCD after adjusting for age, angiotensin-converting enzyme inhibitor (ACE-I)/ angiotensin receptor blockade (ARB) use and major disease risk factors [79].

ACE-I or ARB therapy reduces microalbuminuria in patients with SCD. In a phase 2 trial of 36 children and adults, $a \geq 25 \%$ reduction in urine albumin-tocreatinine ratio was observed in $83 \%(p<0.0001)$ and 
$58 \%(p<0.0001)$ of patients with macroalbuminuria ( $>300 \mathrm{mg} / \mathrm{g}$ creatinine) and microalbuminuria (30-300 mg/g creatinine), respectively, after 6 months of treatment with losartan at a dose of $0.7 \mathrm{mg} / \mathrm{kg} /$ day ( $\max$ of $50 \mathrm{mg}$ ) in children and $50 \mathrm{mg}$ daily in adults [80]. However, ACE-I or ARB therapy has not been shown to improve kidney function or prevent CKD. Hemodialysis is associated with a 1-year mortality rate of $26.3 \%$ after starting hemodialysis and an increase risk of death in SCD patients with ESRD compared to non-SCD patients with ESRD (44.6 vs. $34.5 \%$ deaths, mortality hazard ratio of $2.8,95 \%$ CI $2.31-3.38$ ) [81]. Renal transplant should be considered for individuals with SCD and ESRD because of recent improvements in renal graft survival and post-transplant mortality [82].

\section{Disease-modifying therapies in SCD}

Since publication of its landmark trial in 1995, hydroxyurea continues to represent a mainstay of diseasemodifying therapy for SCD. Hydroxyurea induces fetal hemoglobin production through stress erythropoiesis, reduces inflammation, increases nitric oxide and decreases cell adhesion. The FDA approved hydroxyurea in 1998 for adults with SCD. Subsequently, hydroxyurea was FDA approved for children in 2017 to reduce the frequency pain events and need for blood transfusions in children $\geq 2$ years of age [63]. The landscape of diseasemodifying therapies, however, has improved with the recent FDA approval of 3 other treatments-L-glutamine and crizanlizumab for reducing acute complications (e.g., pain), and voxelotor for improving anemia (Table 3) [8385]. Other therapies in current development focus on inducing fetal hemoglobin, reducing anti-sickling or cellular adhesion, or activating pyruvate kinase-R.

\section{L-glutamine}

Glutamine is required for the synthesis of glutathione, nicotinamide adenine dinucleotide and arginine. The essential amino acid protects red blood cells against oxidative damage, which forms the basis for its proposed utility in SCD. The exact mechanism of benefit in SCD, however, remains unclear. In a phase $3 \mathrm{RCT}$ of 230 participants (hemoglobin SS or $\mathrm{S} / \beta^{0}$ thalassemia), L-glutamine compared to placebo was associated with fewer pain events (median 3 vs. $4, p=0.005$ ) and hospitalizations for pain (median 2 vs. $3, p=0.005$ ) over the 48 -week treatment period [84]. The percentage of patients who had at least 1 episode of acute chest syndrome, defined as presence of chest wall pain with fever and a new pulmonary infiltrate, was lower in the L-glutamine group (8.6 vs. $23.1 \%, p=0.003)$. There were no significant betweengroup differences in hemoglobin, hematocrit or reticulocyte count. Common side effects of L-glutamine include GI upset (constipation, nausea, vomiting and abdominal pain) and headaches.

\section{Crizanlizumab}

P-selectin expression, triggered by inflammation, promotes adhesion of neutrophils, activated platelets and sickle red blood cells to the endothelial surface and to each other, which promotes vaso-occlusion in SCD. Crizanlizumab, given as a monthly intravenous infusion, is a humanized monoclonal antibody that binds P-selectin and blocks the adhesion molecule's interaction with its ligand, P-selectin glycoprotein ligand 1. FDA approval for crizanlizumab was based on a phase 2 RCT $(n=198$, all genotypes), in which the median rate of pain events (primary endpoint) was lower (1.63 vs. $2.68, p=0.01$ ) and time to first pain event (secondary endpoint) was longer (4.07 vs. 1.38 months, $p=0.001$ ) for patients on high-dose crizanlizumab (5 mg/kg/dose) compared to placebo treated for 52 weeks (14 doses total) [83]. In this trial, patients with SCD on chronic transfusion therapy were excluded, but those on stable hydroxyurea dosing were not. Adverse events were uncommon but included headache, back pain, nausea, arthralgia and pain in the extremity.

\section{Voxelotor}

Polymerization of $\mathrm{Hb} \mathrm{S}$ in the deoxygenated state represents the initial step in red blood cell sickling, which leads to reduced red blood cell deformability and increased hemolysis. Voxelotor is a first-in-class allosteric modifier of $\mathrm{Hb} \mathrm{S}$ that increases oxygen affinity. The primary endpoint for the phase $3 \mathrm{RCT}$ of voxelotor $(n=274$, all genotypes) that led to FDA approval was an increase in hemoglobin of at least $1 \mathrm{~g} / \mathrm{dL}$ after 24 weeks of treatment [85]. More participants receiving $1500 \mathrm{mg}$ daily of oral voxelotor versus placebo had a hemoglobin response of at least $1 \mathrm{~g} / \mathrm{dL}(51 \%, 95 \% \mathrm{CI} 41-61$ vs. 7\%, 95\% CI $1-12, \mathrm{p}<0.001)$. Approximately $2 / 3$ of the participants in these trials were on hydroxyurea, with treatment benefits observed regardless of hydroxyurea status. Despite improvements associated with voxelotor in biomarkers of hemolysis (reticulocyte count, indirect bilirubin and lactate dehydrogenase), annualized incidence rate of vasoocclusive crisis was not significantly different among treatment groups. Adverse events included headaches, GI symptoms, arthralgia, fatigue and rash. 


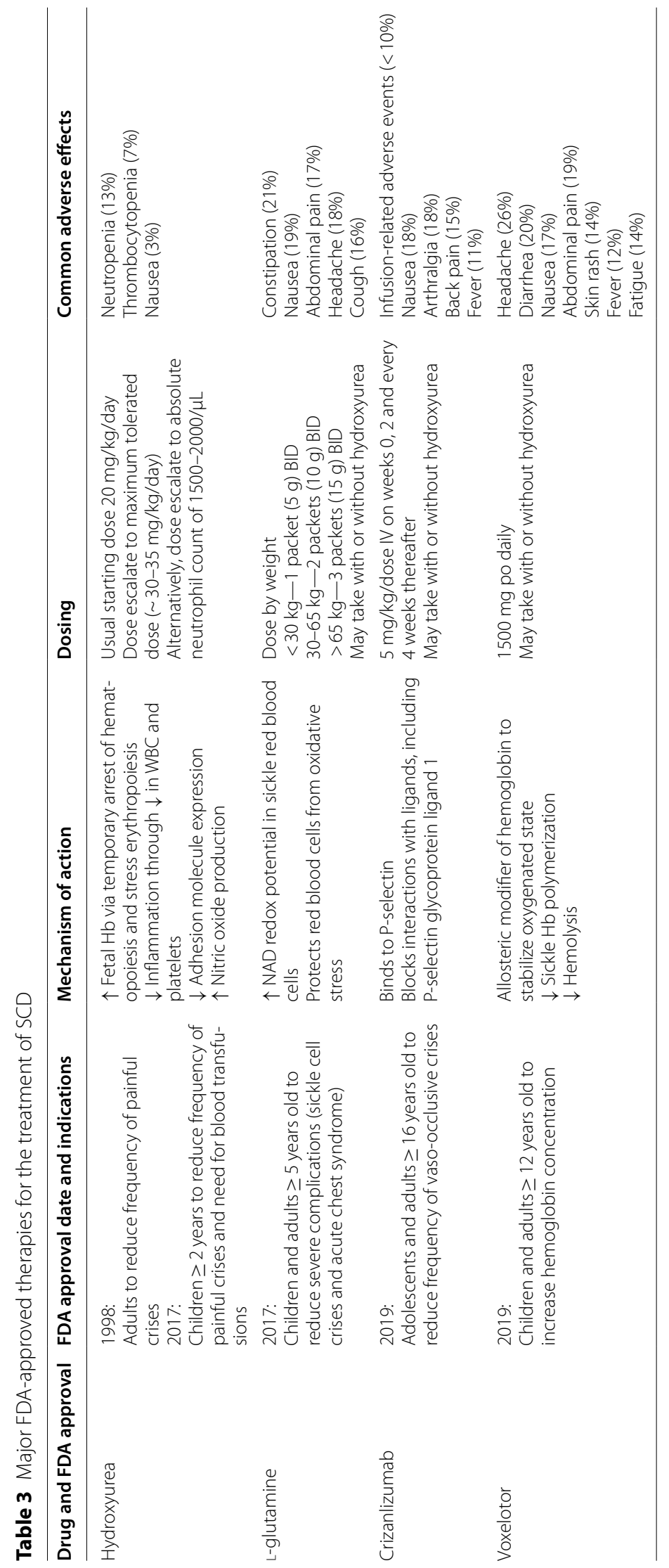




\section{Curative therapies in SCD}

For individuals with SCD undergoing hematopoietic stem cell transplantation (HSCT) using HLA-matched sibling donors and either myeloablative or reducedintensity conditioning regimens, the five-year event-free and overall survival is high at $91 \%$ and $93 \%$, respectively [86]. Limited availability of HLA-matched sibling donors in this population requires alternative donors or the promise of autologous strategies such as genebased therapies (i.e. gene addition, transfer or editing) (Table 4). Matched unrelated donors have not been used routinely due to increased risk of graft-versus-host disease (GVHD) as high as 19\% (95\% CI 12-28) in the first 100 days for acute GVHD and 29\% (95\% CI 21-38) over 3 years for chronic GVHD [87]. Haplo-identical HSCT, using biological parents or siblings as donors, that incorporate post-transplant cyclophosphamide demonstrates acceptable engraftment rates, transplant-related morbidity and overall mortality [88]. Regardless of allogeneic HSCT type, older age is associated with lower event-free (102/418 vs. $72 / 491$ events, HR $1.74,95 \%$ CI $1.24-2.45)$ and overall survival (54/418 vs. 22/491 events, HR 3.15, 95\% CI 1.86-5.34) in patients $\geq 13$ years old compared to $<12$ years old undergoing HSCT [87].

\section{Advancing research in SCD}

Despite progress to date, additional high-quality, longitudinal data are needed to better understand the natural history of the disease and to inform optimal screening for SCD-related complications. In the era of multiple FDA-approved therapies with disease-modifying potential, clinical trials to evaluate additional indications and test them in combination with or compared to each other are needed. Dissemination and implementation studies are also needed to identify barriers and facilitators related to treatment in everyday life, which can be incorporated into decision aids and treatment algorithms for patients and their providers [89]. Lastly, continued efforts should acknowledge social determinants of health and other factors that affect access and disease-related outcomes such as the role of third-party payers, provider and patient education, health literacy and patient trust. Establishing evidencederived quality of care metrics can also drive public policy changes required to ensure care optimization for this population.

\section{Conclusions}

SCD is associated with complications that include acute and chronic pain as well as end-organ damage such as cardiopulmonary, cerebrovascular and kidney disease that result in increased morbidity and mortality. Several well-designed clinical trials have resulted in key advances in management of SCD in the past decade. Data from these trials have led to FDA approval of 3 new drugs, L-glutamine, crizanlizumab and voxelotor, which prevent acute pain and improve chronic

Table 4 Therapies with curative intent

Allogeneic hematopoietic stem cell transplant HLA-matched sibling donor

Umbilical cord donor

HLA-matched unrelated donor

Haploidentical donor

Autologous gene-based therapy

Gene addition or transfer
Standard approaches rely on myeloablative conditioning with overall and disease-free survival rates in the $90 \%$ range for children and young adults with SCD

Reduced intensity and reduced toxicity, nonmyeloablative regimens offer alternative strategies to achieve stable, mixed chimerism in adults with SCD

Cord units from related or unrelated donors represent alternative sources of hematopoietic stem cells for children with SCD; routine use is limited by lower total cell dose

Units from unrelated donors are associated with higher risk of graft rejection and graft-versus-host disease

Demographics of current donor pool limit this option for Black patients with SCD High rates of acute and chronic graft-versus-host disease remain a significant challenge

Haploidentical donors offer most accessible donor type for children and adults with SCD

Strategies focused on T-cell depletion using post-transplant cyclophosphamide have improved engraftment rates and reduced graft-versus-host disease

Lentiviral-based vector encodes modified $\beta$ - or $\gamma$-globin transgenes to increase anti-sickling hemoglobin production

Lentiviral-based vector transfers short-hairpin RNA (shRNA) targeting BCL11A to increase $\gamma$-globin expression

Transduction efficiency is high with current vectors

Concerns remain about risk of insertional oncogenesis and long-term high-level expression

Gene editing 
anemia. Moderate to high-quality data support recommendations for managing SCD cerebrovascular disease and early kidney disease. However, further research is needed to determine the best treatment for chronic pain and cardiopulmonary disease in SCD. Comparative effectiveness research, dissemination and implementation studies and a continued focus on social determinants of health are also essential.

$\begin{array}{ll}\text { Abbreviations } \\ \text { 6-MWD } & \text { Six-minute walk distance } \\ \text { ACE-I } & \text { Angiotensin-converting enzyme inhibitor } \\ \text { ARB } & \text { Angiotensin receptor blockade } \\ \text { CBT } & \text { Cognitive behavioral therapy } \\ \text { CKD } & \text { Chronic kidney disease } \\ \text { COT } & \text { Chronic opioid therapy } \\ \text { ECHO } & \text { Echocardiogram } \\ \text { ESRD } & \text { End stage renal disease } \\ \text { FLAIR } & \text { Fluid-attenuated inversion recovery } \\ \text { GFR } & \text { Glomerular filtration rate } \\ \text { GVHD } & \text { Graft-versus-host disease } \\ \text { HbS } & \text { Hemoglobin S } \\ \text { HSCT } & \text { Hematopoietic stem cell transplant } \\ \text { NSAIDs } & \text { Nonsteroidal anti-inflammatory drugs } \\ \text { NT-proBNP } & \text { N-terminal pro-brain natriuretic peptide } \\ \text { NYHA } & \text { New York Heart Association } \\ \text { PAH } & \text { Pulmonary arterial hypertension } \\ \text { PFT } & \text { Pulmonary function test } \\ \text { PH } & \text { Pulmonary hypertension } \\ \text { PPV } & \text { Positive predictive value } \\ \text { PROs } & \text { Patient-reported outcomes } \\ \text { RCT } & \text { Randomized controlled trial } \\ \text { SCD } & \text { Sickle cell disease } \\ \text { SNRIs } & \text { Serotonin and norepinephrine reuptake inhibitors } \\ \text { TCAs } & \text { Tricyclic antidepressants } \\ \text { TCD } & \text { Transcranial Doppler } \\ \text { tPA } & \text { Tissue plasminogen activator } \\ \text { TRJV } & \text { Tricuspid regurgitant jet velocity } \\ \text { VAS } & \text { Visual Analog Scale } \\ & \\ & \end{array}$

Acknowledgements

We would like to acknowledge Lana Mucalo, MD, for supporting data collection for this manuscript.

\section{Authors' contributions}

$A B$ and $R L$ contributed equally to the writing and editing of this manuscript. All authors read and approved the final manuscript.

\section{Funding}

Not applicable.

\section{Availability of data and materials}

Not applicable.

\section{Declarations}

Ethics approval and consent to participate Not applicable.

\section{Consent for publication}

Not applicable.

\section{Competing interests}

The authors have no competing interests to declare.
Received: 30 September 2021 Accepted: 15 February 2022

Published online: 03 March 2022

\section{References}

1. Piel FB, Patil AP, Howes RE, Nyangiri OA, Gething PW, Dewi M, et al. Global epidemiology of sickle haemoglobin in neonates: a contemporary geostatistical model-based map and population estimates. Lancet. 2013;381 (9861):142-51.

2. Brousseau DC, Panepinto JA, Nimmer M, Hoffmann RG. The number of people with sickle-cell disease in the United States: national and state estimates. Am J Hematol. 2010;85(1):77-8.

3. Payne AB, Mehal JM, Chapman C, Haberling DL, Richardson LC, Bean CJ, et al. Trends in sickle cell disease-related mortality in the United States, 1979 to 2017. Ann Emerg Med. 2020;76(3S):S28-36.

4. Brousseau DC, Owens PL, Mosso AL, Panepinto JA, Steiner CA. Acute care utilization and rehospitalizations for sickle cell disease. JAMA. 2010;303(13):1288-94.

5. Sil S, Cohen LL, Dampier C. Psychosocial and functional outcomes in youth with chronic sickle cell pain. Clin J Pain. 2016;32(6):527-33.

6. Smith WR, Penberthy LT, Bovbjerg VE, McClish DK, Roberts JD, Dahman $B$, et al. Daily assessment of pain in adults with sickle cell disease. Ann Intern Med. 2008:148(2):94-101.

7. Ballas SK, Darbari DS. Neuropathy, neuropathic pain, and sickle cell disease. Am J Hematol. 2013;88(11):927-9.

8. Sharma D, Brandow AM. Neuropathic pain in individuals with sickle cell disease. Neurosci Lett. 2020;714:134445.

9. Dampier C, Palermo TM, Darbari DS, Hassell K, Smith W, Zempsky W. AAPT diagnostic criteria for chronic sickle cell disease pain. J Pain. 2017:18(5):490-8.

10. Darbari DS, Hampson JP, Ichesco E, Kadom N, Vezina G, Evangelou I, et al. Frequency of hospitalizations for pain and association with altered brain network connectivity in sickle cell disease. J Pain. 2015:16(11):1077-86.

11. Levenson JL, Mcclish DK, Dahman BA, Bovbjerg VE, Penberthy LT, et al. Depression and anxiety in adults with sickle cell disease: the PiSCES project. Psychosom Med. 2008;70(2):192-6.

12. Treadwell MJBB, Kaur K, Gildengorin G. Emotional distress, barriers to care, and health-related quality of life in sickle cell disease. J Clin Outcomes Manag. 2015;22:10.

13. Jonassaint $C R$, Jones $V L$, Leong $S$, Frierson $G M$. A systematic review of the association between depression and health care utilization in children and adults with sickle cell disease. Br J Haematol. 2016;174(1):136-47.

14. Laurence B, George D, Woods D. Association between elevated depressive symptoms and clinical disease severity in African-American adults with sickle cell disease. J Natl Med Assoc. 2006;98(3):365-9.

15. Kroenke K, Spitzer RL, Williams JB. The PHQ-9: validity of a brief depression severity measure. J Gen Intern Med. 2001;16(9):606-13.

16. Faulstich ME, Carey MP, Ruggiero L, Enyart P, Gresham F. Assessment of depression in childhood and adolescence: an evaluation of the Center for Epidemiological Studies Depression Scale for Children (CES-DC). Am J Psychiatry. 1986;143(8):1024-7.

17. Spielberger CD, Gorsuch RL, Lushene R, Vagg PR, Jacobs GA. Manual for the state-trait anxiety inventory. Palo Alto: Consulting Psychologists Press; 1983.

18. Brandow AM, Carroll CP, Creary S, Edwards-Elliott R, Glassberg J, Hurley RW, et al. American Society of Hematology 2020 guidelines for sickle cell disease: management of acute and chronic pain. Blood Adv. 2020;4(12):2656-701.

19. Lubega FA, DeSilva MS, Munube D, Nkwine R, Tumukunde J, Agaba PK, et al. Low dose ketamine versus morphine for acute severe vaso occlusive pain in children: a randomized controlled trial. Scand J Pain. 2018;18(1):19-27.

20. Nobrega R, Sheehy KA, Lippold C, Rice AL, Finkel JC, Quezado ZMN. Patient characteristics affect the response to ketamine and opioids during the treatment of vaso-occlusive episode-related pain in sickle cell disease. Pediatr Res. 2018;83(2):445-54. 
21. Perlin E, Finke H, Castro O, Rana S, Pittman J, Burt R, et al. Enhancement of pain control with ketorolac tromethamine in patients with sickle cell vaso-occlusive crisis. Am J Hematol. 1994;46(1):43-7.

22. Beiter JL Jr, Simon HK, Chambliss CR, Adamkiewicz T, Sullivan K. Intravenous ketorolac in the emergency department management of sickle cell pain and predictors of its effectiveness. Arch Pediatr Adolesc Med. 2001:155(4):496-500.

23. Chou R, Turner JA, Devine EB, Hansen RN, Sullivan SD, Blazina I, et al. The effectiveness and risks of long-term opioid therapy for chronic pain: a systematic review for a National Institutes of Health Pathways to Prevention Workshop. Ann Intern Med. 2015;162(4):276-86.

24. Molokie RE, Wilkie DJ, Wittert H, Suarez ML, Yao Y, Zhao Z, et al. Mechanism-driven phase I translational study of trifluoperazine in adults with sickle cell disease. Eur J Pharmacol. 2014;723:419-24.

25. Schlaeger JM, Molokie RE, Yao Y, Suarez ML, Golembiewski J, Wilkie DJ, et al. Management of sickle cell pain using pregabalin: a pilot study. Pain Manag Nurs. 2017;18(6):391-400.

26. Osunkwo I, Ziegler TR, Alvarez J, McCracken C, Cherry K, Osunkwo CE, et al. High dose vitamin $\mathrm{D}$ therapy for chronic pain in children and adolescents with sickle cell disease: results of a randomized double blind pilot study. Br J Haematol. 2012;159(2):211-5.

27. Hauser W, Urrutia G, Tort S, Uceyler N, Walitt B. Serotonin and noradrenaline reuptake inhibitors (SNRIs) for fibromyalgia syndrome. Cochrane Database Syst Rev. 2013;1:CD010292.

28. Hauser W, Wolfe F, Tolle T, Uceyler N, Sommer C. The role of antidepressants in the management of fibromyalgia syndrome: a systematic review and meta-analysis. CNS Drugs. 2012;26(4):297-307.

29. Derry S, Cording M, Wiffen PJ, Law S, Phillips T, Moore RA. Pregabalin for pain in fibromyalgia in adults. Cochrane Database Syst Rev. 2016;9:CD011790.

30. Sil S, Lai K, Lee JL, Gilleland Marchak J, Thompson B, Cohen L, et al. Preliminary evaluation of the clinical implementation of cognitivebehavioral therapy for chronic pain management in pediatric sickle cell disease. Complement Ther Med. 2020;49:102348.

31. Lu K, Cheng MC, Ge X, Berger A, Xu D, Kato GJ, et al. A retrospective review of acupuncture use for the treatment of pain in sickle cell disease patients: descriptive analysis from a single institution. Clin J Pain. 2014;30(9):825-30

32. Mahmood LA, Reece-Stremtan S, Idiokitas R, Martin B, Margulies S, Hardy SJ, et al. Acupuncture for pain management in children with sickle cell disease. Complement Ther Med. 2020;49:102287.

33. Mehari A, Alam S, Tian X, Cuttica MJ, Barnett CF, Miles G, et al. Hemodynamic predictors of mortality in adults with sickle cell disease. Am J Respir Crit Care Med. 2013;187(8):840-7.

34. Cohen RT, Strunk RC, Rodeghier M, Rosen CL, Kirkham FJ, Kirkby J, et al. Pattern of lung function is not associated with prior or future morbidity in children with sickle cell anemia. Ann Am Thorac Soc. 2016;13(8):1314-23.

35. Kassim AA, Payne AB, Rodeghier M, Macklin EA, Strunk RC, DeBaun MR. Low forced expiratory volume is associated with earlier death in sickle cell anemia. Blood. 2015;126(13):1544-50.

36. Sharma S, Efird JT, Knupp C, Kadali R, Liles D, Shiue K, et al. Sleep disorders in adult sickle cell patients. J Clin Sleep Med. 2015;11(3):219-23.

37. Rosen CL, Debaun MR, Strunk RC, Redline S, Seicean S, Craven DI, et al. Obstructive sleep apnea and sickle cell anemia. Pediatrics. 2014;134(2):273-81.

38. Simonneau G, Montani D, Celermajer DS, Denton CP, Gatzoulis MA, Krowka M, et al. Haemodynamic definitions and updated clinical classification of pulmonary hypertension. Eur Respir J. 2019;53(1).

39. Chaturvedi S, Labib Ghafuri D, Kassim A, Rodeghier M, DeBaun MR. Elevated tricuspid regurgitant jet velocity, reduced forced expiratory volume in 1 second, and mortality in adults with sickle cell disease. Am J Hematol. 2017;92(2):125-30.

40. Parent F, Bachir D, Inamo J, Lionnet F, Driss F, Loko G, et al. A hemodynamic study of pulmonary hypertension in sickle cell disease. N Engl J Med. 2011;365(1):44-53.

41. Machado RF, Anthi A, Steinberg MH, Bonds D, Sachdev V, Kato GJ, et al. $\mathrm{N}$-terminal pro-brain natriuretic peptide levels and risk of death in sickle cell disease. JAMA. 2006;296(3):310-8.

42. Mondal P, Yirinec A, Midya V, Sankoorikal BJ, Smink G, Khokhar A, et al. Diagnostic value of spirometry vs impulse oscillometry: a comparative study in children with sickle cell disease. Pediatr Pulmonol. 2019;54(9):1422-30.

43. Field JJ, Stocks J, Kirkham FJ, Rosen CL, Dietzen DJ, Semon T, et al. Airway hyperresponsiveness in children with sickle cell anemia. Chest. 2011;139(3):563-8.

44. Dlamini N, Saunders DE, Bynevelt M, Trompeter S, Cox TC, Bucks RS, et al. Nocturnal oxyhemoglobin desaturation and arteriopathy in a pediatric sickle cell disease cohort. Neurology. 2017;89(24):2406-12.

45. Barst RJ, Mubarak KK, Machado RF, Ataga Kl, Benza RL, Castro O, et al. Exercise capacity and haemodynamics in patients with sickle cell disease with pulmonary hypertension treated with bosentan: results of the ASSET studies. Br J Haematol. 2010;149(3):426-35.

46. Machado RF, Barst RJ, Yovetich NA, Hassell KL, Kato GJ, Gordeuk VR, et al. Hospitalization for pain in patients with sickle cell disease treated with sildenafil for elevated TRV and low exercise capacity. Blood. 2011;118(4):855-64.

47. Turpin M, Chantalat-Auger C, Parent F, Driss F, Lionnet F, Habibi A, et al. Chronic blood exchange transfusions in the management of pre-capillary pulmonary hypertension complicating sickle cell disease. European Respiratory Journal. 2018;52(4).

48. Knight-Madden JM, Barton-Gooden A, Weaver SR, Reid M, Greenough A. Mortality, asthma, smoking and acute chest syndrome in young adults with sickle cell disease. Lung. 2013;191(1):95-100.

49. Strunk RC, Cohen RT, Cooper BP, Rodeghier M, Kirkham FJ, Warner JO, et al. Wheezing symptoms and parental asthma are associated with a physician diagnosis of asthma in children with sickle cell anemia. J Pediatr. 2014;164(4):821-6e1.

50. Takahashi T, Okubo Y, Handa A. Acute chest syndrome among children hospitalized with vaso-occlusive crisis: a nationwide study in the United States. Pediatr Blood Cancer. 2018;65(3):e26885.

51. Glassberg J, Minnitti C, Cromwell C, Cytryn L, Kraus T, Skloot GS, et al. Inhaled steroids reduce pain and sVCAM levels in individuals with sickle cell disease: a triple-blind, randomized trial. Am J Hematol. 2017;92(7):622-31.

52. Ohene-Frempong K, Weiner SJ, Sleeper LA, Miller ST, Embury S, Moohr JW, et al. Cerebrovascular accidents in sickle cell disease: rates and risk factors. Blood. 1998;91 (1):288-94.

53. Bernaudin F, Verlhac S, Arnaud C, Kamdem A, Vasile M, Kasbi F, et al. Chronic and acute anemia and extracranial internal carotid stenosis are risk factors for silent cerebral infarcts in sickle cell anemia. Blood. 2015;125(10):1653-61.

54. Kassim AA, Pruthi S, Day M, Rodeghier M, Gindville MC, Brodsky MA, et al. Silent cerebral infarcts and cerebral aneurysms are prevalent in adults with sickle cell anemia. Blood. 2016;127(16):2038-40.

55. Powars D, Wilson B, Imbus C, Pegelow C, Allen J. The natural history of stroke in sickle cell disease. Am J Med. 1978;65(3):461-71.

56. Switzer JA, Hess DC, Nichols FT, Adams RJ. Pathophysiology and treatment of stroke in sickle-cell disease: present and future. Lancet Neurol. 2006;5(6):501-12.

57. DeBaun MR, Gordon M, McKinstry RC, Noetzel MJ, White DA, Sarnaik SA, et al. Controlled trial of transfusions for silent cerebral infarcts in sickle cell anemia. N Engl J Med. 2014;371 (8):699-710.

58. DeBaun MR, Jordan LC, King AA, Schatz J, Vichinsky E, Fox CK, et al. American Society of Hematology 2020 guidelines for sickle cell disease: prevention, diagnosis, and treatment of cerebrovascular disease in children and adults. Blood Adv. 2020;4(8):1554-88.

59. Dobson SR, Holden KR, Nietert PJ, Cure JK, Laver JH, Disco D, et al. Moyamoya syndrome in childhood sickle cell disease: a predictive factor for recurrent cerebrovascular events. Blood. 2002;99(9):3144-50.

60. Adams RJ, McKie VC, Hsu L, Files B, Vichinsky E, Pegelow C, et al. Prevention of a first stroke by transfusions in children with sickle cell anemia and abnormal results on transcranial Doppler ultrasonography. N Engl J Med. 1998;339(1):5-11.

61. Vichinsky EP, Neumayr LD, Gold JI, Weiner MW, Rule RR, Truran D, et al. Neuropsychological dysfunction and neuroimaging abnormalities in neurologically intact adults with sickle cell anemia. JAMA. 2010;303(18):1823-31.

62. Hijmans CT, Fijnvandraat K, Grootenhuis MA, van Geloven N, Heijboer H, Peters $\mathrm{M}$, et al. Neurocognitive deficits in children with sickle cell disease: a comprehensive profile. Pediatr Blood Cancer. 2011;56(5):783-8. 
63. Ware RE, Davis BR, Schultz WH, Brown RC, Aygun B, Sarnaik S, et al. Hydroxycarbamide versus chronic transfusion for maintenance of transcranial doppler flow velocities in children with sickle cell anaemia-TCD With Transfusions Changing to Hydroxyurea (TWiTCH): a multicentre, open-label, phase 3, non-inferiority trial. Lancet. 2016;387(10019):661-70.

64. Scothorn DJ, Price C, Schwartz D, Terrill C, Buchanan GR, Shurney W, et al. Risk of recurrent stroke in children with sickle cell disease receiving blood transfusion therapy for at least five years after initial stroke. J Pediatr. 2002;140(3):348-54.

65. Hulbert ML, Scothorn DJ, Panepinto JA, Scott JP, Buchanan GR, Sarnaik $S$, et al. Exchange blood transfusion compared with simple transfusion for first overt stroke is associated with a lower risk of subsequent stroke: a retrospective cohort study of 137 children with sickle cell anemia. J Pediatr. 2006;149(5):710-2.

66. Hall EM, Leonard J, Smith JL, Guilliams KP, Binkley M, Fallon RJ, et al. Reduction in overt and silent stroke recurrence rate following cerebral revascularization surgery in children with sickle cell disease and severe cerebral vasculopathy. Pediatr Blood Cancer. 2016;63(8):1431-7.

67. Lebensburger JD, Aban I, Pernell B, Kasztan M, Feig DI, Hilliard LM, et al. Hyperfiltration during early childhood precedes albuminuria in pediatric sickle cell nephropathy. Am J Hematol. 2019;94(4):417-23.

68. Niss O, Lane A, Asnani MR, Yee ME, Raj A, Creary S, et al. Progression of albuminuria in patients with sickle cell anemia: a multicenter, longitudinal study. Blood Adv. 2020;4(7):1501-11.

69. Cazenave M, Audard V, Bertocchio JP, Habibi A, Baron S, Prot-Bertoye C, et al. Tubular acidification defect in adults with sickle cell disease. Clin J Am Soc Nephrol. 2020;15(1):16-24.

70. Yee MEM, Lane PA, Archer DR, Joiner CH, Eckman JR, Guasch A. Estimation of glomerular filtration rate using serum cystatin $C$ and creatinine in adults with sickle cell anemia. Am J Hematol. 2017;92(10):E598-9.

71. Yawn BP, Buchanan GR, Afenyi-Annan AN, Ballas SK, Hassell KL, James AH, et al. Management of sickle cell disease: summary of the 2014 evidencebased report by expert panel members. JAMA. 2014;312(10):1033-48.

72. Saraf SL, Zhang X, Shah B, Kanias T, Gudehithlu KP, Kittles R, et al. Genetic variants and cell-free hemoglobin processing in sickle cell nephropathy. Haematologica. 2015;100(10):1275-84.

73. Hamideh D, Raj V, Harrington T, Li H, Margolles E, Amole F, et al. Albuminuria correlates with hemolysis and NAG and KIM-1 in patients with sickle cell anemia. Pediatr Nephrol. 2014;29(10):1997-2003.

74. dos Santos TE, Goncalves RP, Barbosa MC, da Silva GB, Jr., Daher Ede F. Monocyte chemoatractant protein-1: a potential biomarker of renal lesion and its relation with oxidative status in sickle cell disease. Blood Cells Mol Dis. 2015;54(3):297-301.

75. Audard V, Moutereau S, Vandemelebrouck G, Habibi A, Khellaf M, Grimbert P, et al. First evidence of subclinical renal tubular injury during sickle-cell crisis. Orphanet J Rare Dis. 2014;9:67.

76. Baddam S, Aban I, Hilliard L, Howard T, Askenazi D, Lebensburger JD. Acute kidney injury during a pediatric sickle cell vaso-occlusive pain crisis. Pediatr Nephrol. 2017:32(8):1451-6.

77. Zahr RS, Hankins JS, Kang G, Li C, Wang WC, Lebensburger J, et al. Hydroxyurea prevents onset and progression of albuminuria in children with sickle cell anemia. Am J Hematol. 2019;94(1):E27-9.

78. Alvarez O, Miller ST, Wang WC, Luo Z, McCarville MB, Schwartz GJ, et al. Effect of hydroxyurea treatment on renal function parameters: results from the multi-center placebo-controlled BABY HUG clinical trial for infants with sickle cell anemia. Pediatr Blood Cancer. 2012;59(4):668-74.

79. Laurin LP, Nachman PH, Desai PC, Ataga KI, Derebail VK. Hydroxyurea is associated with lower prevalence of albuminuria in adults with sickle cell disease. Nephrol Dial Transplant. 2014;29(6):1211-8.

80. Quinn CT, Saraf SL, Gordeuk VR, Fitzhugh CD, Creary SE, Bodas P, et al. Losartan for the nephropathy of sickle cell anemia: a phase-2, multicenter trial. Am J Hematol. 2017;92(9):E520-8.

81. McClellan AC, Luthi JC, Lynch JR, Soucie JM, Kulkarni R, Guasch A, et al. High one year mortality in adults with sickle cell disease and end-stage renal disease. Br J Haematol. 2012;159(3):360-7.

82. Gérardin C, Moktefi A, Couchoud C, Duquesne A, Ouali N, Gataut P, et al. Survival and specific outcome of sickle cell disease patients after renal transplantation. Br J Haematol. 2019;187(5):676-80.

83. Ataga Kl, Kutlar A, Kanter J, Liles D, Cancado R, Friedrisch J, et al. Crizanlizumab for the prevention of pain crises in sickle cell disease. N Engl Med. 2017:376(5):429-39.
84. Niihara Y, Miller ST, Kanter J, Lanzkron S, Smith WR, Hsu LL, et al. A phase 3 trial of L-glutamine in sickle cell disease. N Engl J Med. 2018:379(3):226-35

85. Vichinsky E, Hoppe CC, Ataga KI, Ware RE, Nduba V, El-Beshlawy A, et al. A phase 3 randomized trial of voxelotor in sickle cell disease. N Engl J Med. 2019;381(6):509-19.

86. Gluckman E, Cappelli B, Bernaudin F, Labopin M, Volt F, Carreras J, et al. Sickle cell disease: an international survey of results of HLAidentical sibling hematopoietic stem cell transplantation. Blood. 2017;129(11):1548-56.

87. Eapen M, Brazauskas R, Walters MC, Bernaudin F, Bo-Subait K, Fitzhugh $C D$, et al. Effect of donor type and conditioning regimen intensity on allogeneic transplantation outcomes in patients with sickle cell disease: a retrospective multicentre, cohort study. Lancet Haematol. 2019;6(11):e585-96.

88. Bolanos-Meade J, Cooke KR, Gamper CJ, Ali SA, Ambinder RF, Borrello $I M$, et al. Effect of increased dose of total body irradiation on graft failure associated with HLA-haploidentical transplantation in patients with severe haemoglobinopathies: a prospective clinical trial. Lancet Haematol. 2019:6(4):e183-93.

89. Krishnamurti L, Ross D, Sinha C, Leong T, Bakshi N, Mittal N, et al. Comparative effectiveness of a web-based patient decision aid for therapeutic options for sickle cell disease: randomized controlled trial. J Med Internet Res. 2019;21(12):e14462.

\section{Publisher's Note}

Springer Nature remains neutral with regard to jurisdictional claims in published maps and institutional affiliations.

Ready to submit your research? Choose BMC and benefit from

- fast, convenient online submission

- thorough peer review by experienced researchers in your field

- rapid publication on acceptance

- support for research data, including large and complex data types

- gold Open Access which fosters wider collaboration and increased citations

- maximum visibility for your research: over 100M website views per year

At BMC, research is always in progress.

Learn more biomedcentral.com/submissions 